\title{
RELATIONSHIP BETWEEN PHYSICAL ACTIVITY AND HEALTH-RELATED QUALITY OF LIFE IN ELDERLY PEOPLE: ACROSS-SECTION STUDY
}

\author{
Walid Kamal M. Abdelbasset, ${ }^{1,2}$ Gopal Nambi S. ${ }^{1}$ \\ ${ }^{1}$ Department of physical therapy and health rehabilitation, \\ College of applied medical sciences, Prince Sattam Bin Abdul Aziz University, Alkharj, KSA \\ ${ }^{2}$ Department of physical therapy, Kasr Al-Aini Hospital, Cairo University, Egypt
}

Primljen/Received 30. 04. 2017. god.

Abstract: Objectives: This study aimed to investigate the relationship between physical activitylevel and health related quality of life in elderly people.

Design: Between January and April 2017, a cross-sectional study of 114 elderly people ( 73 males and 41 females) conducted this study. Their mean age was (71 \pm $5.24)$ and the mean body mass index (BMI) was ( $29 \pm$ 3.31). The participating elderly were classified according to walking duration into two groups, low level of physical activity (walking duration $<150 \mathrm{~min} /$ week) and high level of physical activity (walking duration $>300$ $\mathrm{min} /$ week). The health-related quality of life (HRQoL) was measured using the Euro Qol-5dimensions-3 levels scale questionnaire (EQ-5D-3L). Statistical analysis was used to determine the relation between the physical activity and HRQoL scores in elderly people.

Results: The measures showed statistically significant differences between high and low physical activity groups $(\mathrm{p}<0.05)$. The group of high physical activity showed higher HRQoL scores more than the group of low physical activity in the all five dimensions. The low level group showed high predominance of the chronic disease.

Conclusions: High level of physical activity has a beneficial effect on all dimensions of the HRQoL in elderly people. Effort and awareness should be dedicated to encouraging the active lifestyle among different population especially elderly people.

Keywords: elderly, physical activity, HRQoL, EuroQol.

\section{INTRODUCTION}

Aging is rapidly increasing worldwide (1), health governments are highly interested in protecting and
Prihvaćen/Accepted 03. 07. 2017. god.

advancing the level of health with live ignited and sustaining the maximum life quality. Kindred population above 65 years old has heightened significantly in Spain, between 1975 and 2015 from 10-18\% of the total number of people (2).

HRQoL is a health condition symptom of the people's everywhere and it can be a necessity for distinct contexts, as experimental researches, assessments of health care stinting or health of population reconnoiter (3). Many various approaches of HRQL live, the HRQoL was defined as the measure appointed for the life period, which adjusted with the deteriorations, conditions of function, intuitions and possibility socially that are affected through illness, injuries, handling or treatment and guidelines (4). Many templates directing to these various dimensionally thought were suggested throughout these years $(5,6)$.

The HRQoL model comprises of many domains, including overall quality of life (QoL), general health, symptom, biological, and functional statuses, not only the mentioned five domains but also include environmental and individual dimensions. Every domain affects directly on the subsequent domain (function status is affected by symptom status and this affected by biological variables). But the environmental and individual variables influence directly all domains measure except biological domain (5).

The HRQoL is one of many dimensions conceptualization that view social, mental, and physical outlooks (7). The HRQoL evaluation is a critical constituent of physical and mental health assessment (8). Several implements were matured to evaluate HRQoL in various communities. Many important factors are associated with clinical and demographic characteristics, compri- 
sing patient age, medical status, language, and culture of the community are vitalin formation to use a related reliable and valid measure of $\operatorname{HRQoL}(8,9)$.

Physical activity seems to be related to improving functional performance and HRQoL (7, 9, 10, 11). Physical exercise may assist older adults repossess or sustain a the health of aging people (12). Regular leisure time of physical exercise can lead to high level of HRQoL in elderly people $(13,14)$.

Also, regular physical activity may proportionately assist elderly people to inhibit a decrease of HRQoL and enhance the enjoyment of their life (15). Because of these important determinants that support better elderly health, evaluating the relationship between physical activity level and HRQoL scores in elderly people became greater needed, particularly compared to the increase of the elderly number in the world. This study aimed to evaluate the relationship between physical activity and HRQoL scores in elderly people.

\section{SUBJECTS AND METHOD}

Between January and April 2017, a cross sectional study on 114 elderly people (73 males, 41 females) aged $\$ 65$ years were recruited in this study. All participants were considered eligible when they met the inclusion criteria of being independent walking without any cognitive disorders. This independent walking was evaluated according to walking capacity of the participants (can walk at least 6 minutes without assistance) (10). All subjects with severe life limiting illness, orthopaedic limitations, cognitive disorders that couldn't know anything about his age, childhood, and couldn't respond to examiner questions were excluded from this study. The participating elderly were classified according to walking duration into two groups, low level of physical activity (walking duration $<150 \mathrm{~min} /$ week) and high level of physical activity (walking duration $>$ $300 \mathrm{~min} /$ week) (10). Each participant was informed about the objectives and procedure of the study and instructed to sign a written informed consent before starting the study. It was conducted at the outpatient physical therapy department, College of Applied Medical Sciences, Prince Sattam Bin Abdul Aziz University.

\section{Procedure}

Assessment procedures which were done through using the following:

a- Baseline clinical characteristics questionnaire; the patient data were recorded, including; age, gender, height, weight, work, past medical disease, medications, habits, motor or sensory dysfunctions.

b- The HRQoL questionnaire: It was measured using an Arabic version of the Euro Qol-5dimensions-3 levels scale (EQ-5D-3L). It is a standardized instrument for measuring outcomes of health. It is well validated, reliable, and not need more time or effort to be completed and has been documented in many previous studies to measure $\mathrm{HRQOL}$ in a wide range of health conditions (16-18). It includes descriptive system (5 dimensions) and EQ visual analogue scale (EQ-VAS).

The EuroQoL group approved the validated Arabic version of the EQ-5D questionnaire to assess elderly people QoL (19). The EQ-5D comprises 5 dimensions, including; mobility, self care, usual activities, pain/discomfort, anxiety/depression. Each domainconsists of 3 levels (no problems, slight/moderate problems, and severe/extreme problems). EQ-VAS assess HRQoL with 0-100 endpoints, 0 is the lowest imagine health and 100 is the highest imagine health.

\section{Data Analysis}

Descriptive statistics was done in the form of mean and standard deviation to assess the sample based on the physical activity and HRQoL. Mann-Whitney test was used to assess the arranged measures of EQ-5D. The Spearman's correlation coefficient was used to measure the strength and direction of the relationship between the physical activity and HRQoL. All analysis was done using SPSS version 18.0 (SPSS, Chicago, IL) with statistical significance at p-value \# 0.05 .

\section{RESULTS}

114 elderly people (73 males and 41 females) participated in this study. Their mean age was $(71 \pm 5.24)$ and the mean body mass index (BMI) was $(29 \pm 3.31)$. $70.2 \%$ of the participants were diagnosed clinically with chronic disease as the following; $25.4 \%$ diabetes mellitus, $31.6 \%$ hypertension, $13.2 \%$ cardiovascular disease. About $93 \%$ the participating elderly weren't smoking and only $7 \%$ were smoking. Sleep quality was good in $83 \%$ of subjects and bad in $17 \%$ of subjects. Walking duration was less than $30 \mathrm{~min} /$ day in seventy six subjects and more than $30 \mathrm{~min} /$ day in thirty eight subjects. Clinical characteristics of all participating elderly demonstrated in Table 1. Also, clinical characteristics in high and low level of physical activity are demonstrated in Table 2.

The outcomes of HRQoL measures exhibited that the group of low physical activity level suffered walking problems started from slight/moderate to severe/extreme level as $(90.3 \%, 64.5 \%, 85.5 \%, 88.2 \%, 81.6 \%)$ of the participants in mobility, self-care, usual activities, pain/discomfort, and anxiety/depression dimensions respectively. While the group of high physical activity level suffered waking problems only in slight/moderate 
Table 1. Clinical characteristics of the all participants

\begin{tabular}{|l|c|}
\hline \multicolumn{1}{|c|}{ Characteristics } & N (\%) \\
\hline Sex & $73(64)$ \\
Males n (\%) & $41(36)$ \\
Females n (\%) & $71 \pm 5.24$ \\
\hline Age mean \pm SD & $161 \pm 3.4$ \\
\hline Height (cm) mean \pm SD & $76 \pm 7.14$ \\
\hline Weight (kg) mean \pm SD & $29 \pm 3.31$ \\
\hline BMI (kg/m $\left.{ }^{2}\right)$ mean \pm SD & $80(70.2) / 24(29.8)$ \\
\hline Medical diagnosed chronic disease \\
\hline Yes/No n (\%) & $29(25.4)$ \\
\hline Diabetes Mellitus & $36(31.6)$ \\
\hline Hypertension & $15(13.2)$ \\
\hline Cardiovascular & $8(7) / 106(93 \%)$ \\
\hline Smoking habits (yes/no) & $95 / 19$ \\
\hline Sleep quality (good/bad) & $76(66.6)$ \\
\hline Walking duration n (\%) & $38(33.4)$ \\
\hline Less than 150 min/week & \\
\hline More than 300 min/week &
\end{tabular}

level as $(36.8 \%, 23.7 \%, 31.6 \%, 60.5 \%, 52.6 \%)$ of the participants in the five dimensions respectively. No participant suffered any walking problems in severe/extreme level in all dimensions in a high physical activity group. The results showed statistically significant differences between the two groups; high and low physical activity groups $(p<0.05)$. The group of high physical activity exhibited higher measures more than the group of low physical activity in the all five dimensions. On EQ-VAS measure, the high level group showed higher scores more than a low level group $(p<0.05)$ as demonstrated in Table 3.

With correlation coefficient statistical analysis, strong positive correlation was exhibited in this study between physical activity level and the all five dimensions of the EuroQol questionnaire. This strong positive correlation means that higher physical activity level goes with high HRQoL scores (and vice versa) as demonstrated in Table 4.

Table 2. Clinical characteristics in the two groups; low and high level of physical activity

\begin{tabular}{|l|c|c|c|}
\hline \multicolumn{1}{|c|}{ Items } & $\begin{array}{c}\text { Low physical activity } \\
(\mathbf{n = 7 6 )}\end{array}$ & $\begin{array}{c}\text { High physical activity } \\
(\mathbf{n = 3 8})\end{array}$ & p-value \\
\hline Sex $(\mathrm{male} / \mathrm{female})$ & $49 / 27$ & $24 / 14$ & $<0.05$ \\
\hline BMI $\left(\mathrm{kg} / \mathrm{m}^{2}\right)$ & $31.2 \pm 3.5$ & $29.3 \pm 4.2$ & $<0.05$ \\
\hline Chronic disease $\mathrm{n}(\%)$ & $71(93.4)$ & $9(23.7)$ & $<0.05$ \\
\hline Diabetes mellitus $\mathrm{n}(\%)$ & $27(35.5)$ & $2(5.3)$ & $<0.05$ \\
\hline Hypertension n (\%) & $32(42.1)$ & $4(10.5)$ & $<0.05$ \\
\hline Cardiovascular disease $\mathrm{n}(\%)$ & $12(15.8)$ & $3(7.9)$ & $<0.05$ \\
\hline
\end{tabular}

Table 3. HRQoL measures in low and high physical activity levels

\begin{tabular}{|c|c|c|c|}
\hline HRQoL items & $\begin{array}{c}\text { Low physical activity } \\
(\mathrm{n}=76)\end{array}$ & $\begin{array}{l}\text { High physical activity } \\
(\mathrm{n}=\mathbf{3 8})\end{array}$ & p-value \\
\hline \multicolumn{4}{|l|}{ Mobility n (\%) } \\
\hline No problems & $7(9.2)$ & $24(63.2)$ & $<0.05$ \\
\hline Slight/Moderate problems & $58(76.3)$ & $14(36.8)$ & $<0.05$ \\
\hline Severe/Extreme problems & $11(14.5)$ & 0 & $<0.05$ \\
\hline \multicolumn{4}{|l|}{ Self-care n (\%) } \\
\hline No problems & $27(35.5)$ & $29(76.3)$ & $<0.05$ \\
\hline Slight/Moderate problems & $43(56.6)$ & $9(23.7)$ & $<0.05$ \\
\hline Severe/Extreme problems & $6(7.9)$ & 0 & $<0.05$ \\
\hline \multicolumn{4}{|l|}{ Usual activities } \\
\hline No problems & $11(14.5)$ & $26(68.4)$ & $<0.05$ \\
\hline Slight/Moderate problems & $51(67.1)$ & $12(31.6)$ & $<0.05$ \\
\hline Severe/Extreme problems & $14(18.4)$ & 0 & $<0.05$ \\
\hline \multicolumn{4}{|l|}{ Pain/discomfort n (\%) } \\
\hline No problems & $9(11.8)$ & $15(39.5)$ & $<0.05$ \\
\hline Slight/Moderate problems & $52(68.4)$ & $23(60.5)$ & $<0.05$ \\
\hline Severe/Extreme problems & $15(19.8)$ & 0 & $<0.05$ \\
\hline \multicolumn{4}{|l|}{ Anxiety/depression n (\%) } \\
\hline No problems & $14(18.4)$ & $18(47.4)$ & $<0.05$ \\
\hline Slight/Moderate problems & $43(56.6)$ & $20(52.6)$ & $<0.05$ \\
\hline Severe/Extreme problems & $19(25)$ & 0 & $<0.05$ \\
\hline EQ-VAS (Mean \pm SD) & $60 \pm 11.42$ & $87 \pm 8.31$ & $<0.05$ \\
\hline
\end{tabular}


Table 4. The Spearman' correlation coefficient between HRQoL and Physical activity levels

\begin{tabular}{|l|c|c|c|}
\hline \multirow{2}{*}{\multicolumn{1}{c|}{ HRQoL items }} & \multicolumn{2}{c|}{$\mathbf{9 5 \%}$ confidence interval } & \multirow{2}{*}{$\mathbf{r}_{\mathbf{s}}$} \\
\cline { 2 - 3 } & Lower & Higher & 0.617 \\
\hline Mobility scores & -0.641 & -0.397 & 0.512 \\
\hline Self-care scores & -0.593 & -0.349 & -0.527 \\
\hline Usual activities scores & -0.628 & -0.351 & -0.356 \\
\hline Pain/discomfort scores & -0.462 & -0.169 & -0.418 \\
\hline Anxiety/depression scores & -0.511 & 0.163 & 0.649 \\
\hline EQ-VAS score & 0.451 & 0.722 & \\
\hline
\end{tabular}

\section{DISCUSSION}

This study aimed to evaluate the effects of physical exercise on elderly HRQoL in a group of functionally independent older people without cognitive disorders. Elderly with cognitive disorders were excluded because this disorder could influence the capability for supporting correct answers. Previous studies has taken same ruling $(20,21)$. The elderly were included in the study as the reliance influences the HRQoL evaluation, because their functional performance could affect it (20). In this study, HRQoL was explored as the elderly were independent and had no cognitive impairments. Therefore, this study was contributed to supply high comprehensive awareness of what factors more functionally distant are related to HRQoL in elderly people. Findings of this study may be beneficial in knowledge of the efficient assessment procedures to support the ideal lifestyle of the elderly people.

Thirty minutes walking had seemed to be directly associated with positive strength of leg muscles and physical capacity in elderly subjects (22). The physical activity was concluded and determined through the waking duration in the present study as the walking is the usual physical activity in aged people and can comfortably be adapted without effort in daily life (23).

In the EuroQoL, there are two functioning and subjective well-being domains that concern the HRQoL assessment in this current study. Functioning evaluation was assessed through mobility, self-care, and usual activities dimensions. While pain/discomfort and anxiety/depression dimensions were used to assess subjective well-being evaluation. Using of Arabic version of the EuroQoL was approved to be an easy and valid measure for elderly QoL (24).

According to findings of this study, the elderly comprised $77 \%$ of the low physical activity and the greater number of elderly documented as they were diagnosed with minimum one disease. The elderly participants with low activity were reported more commonly of lasting illness as, diabetes, hypertension, and cardiovascular disease. Light sports and walking have positive impacts to control cardiovascular disease in postmenopausal women (25).

Many previous studies approved that regular physical activity have significant improvement in health and disease control. High level of physical activity in aged people seemed an international preference (26).

The elderly participants with high activity were high scores of all EuroQoL dimensions. Functioning evaluation domain showed higher records of mobility dimension in a high physical activity group than low physical activity group $(\mathrm{p}<0.05)$. This result supports the high correlation between physical activity and HRQoL. Similar results were approved by Frandin et al as they reported that walkers have a better estimation of physical activity capacity than non-walkers (22).

Also, the elderly with high level of physical activity showed high scores of self-care and usual activities dimensions mentioned in EuroQoL. These two dimensions helped to improve the level independence and physical activity promoting reduction of disability risks in aged people (27). So, the present study investigated the relation between the level of physical activity and functioning domain variables.

In subjective well-being evaluation domain using pain/discomfort and anxiety/depression dimensions, most of all participants in this study showed slight pain/discomfort and slight anxiety/depression. There were significant differences in subjective well-being variables in high levels of physical activity compared with low physical activity level. In agreement with previous studies, the present study approved beneficial effects of physical activity on depression status and pain in elderly people $(28,29)$.

\section{CONCLUSION}

It was concluded that the high level of physical activity has a beneficial effect on all dimensions of the HRQoL in elderly people. Effort and awareness should be dedicated to encouraging the active lifestyle among different population especially elderly people.

\section{Funding}

No funding was received for this study 


\section{Acknowledgement}

The authors thank all elderly who participated in this study.

\section{Declaration of interest}

The authors declare no competing interests.
Abbreviations

BMI — body mass index

HRQoL - related quality of life

EQ-5D-3L - EuroQol-5dimensions-3levels scale questionnaire

EQ-VAS - EQ visual analogue scale

\title{
Sažetak
}

\section{POVEZANOST NIVOA FIZIČKE AKTIVNOSTI I KVALITETA ŽIVOTA KOD STARIH OSOBA: STUDIJA PRESEKA}

\author{
Walid Kamal M. Abdelbasset, ${ }^{1,2}$ Gopal Nambi S. ${ }^{1}$ \\ ${ }^{1}$ Department of physical therapy and health rehabilitation, \\ College of applied medical sciences, Prince Sattam Bin Abdul Aziz University, Alkharj, KSA \\ 2 Department of physical therapy,Kasr Al-Aini Hospital, Cairo University, Egypt
}

Cilj: Cilj ove studije bio je da se ispita povezanost nivoa fizičke aktivnosti i kvaliteta života kod starih. Dizajn: U periodu od januara do aprila 2017. godine, studija preseka je izvedena, i obuhvatala je 114 starih ljudi (73 muškarca i 41 žena). Srednja starosna dob je iznosila (71 $\pm 5.24)$ i srednja vrednost indeksa telesne mase (BMI) bila je $29 \pm 3.31$. Učesnici studije su bili podeljeni na osnovu distance koju su mogli da prepešače u dve grupe - niskoaktivnu grupu (distance $<150 \mathrm{~min} /$ nedeljno) i visoko aktivnu grupu (distance $>300 \mathrm{~min} / \mathrm{nedeljno}$ ). Kvalitet zdravstvenog aspekta života je meren korišćenjem Euro Qol-5 dimension-3 level upitnika (EQ-5D-3L). Statistička analiza je korišćena da ispita povezanost fizičke

\section{REFERENCES}

1. World Health Organization. Good health adds life to years. global brief for world health day 2012. Geneva: WHO Document Production Services; 2012.

2. Spanish National Health Statistics. INEbase: Resident population by date, sex and age. Main series since 1971. Accessed 3 Aug 2016.

3. Khanna D, Tsevat J. Health-related quality of life-an introduction. Am J Manag Care. 2007; 13Suppl 9: S218-23.

4. Patrick DL, Eriksson C. Health status and health policy: Quality of life in health care evaluation and resource allocation. New York: Oxford University Press; 1993.

5. Ferrans CE, Zerwic JJ, Wilbur JE, Larson JL. Conceptual model of health-related quality of life. J NursScholarsh. 2005; 37(4): 336-42.

6. Bakas T, McLennon SM, Carpenter JS, Buelow JM, Otte JL, Hanna KM, et al. Systematic review of health-related quality of life models. Health Qual Life Outcomes. 2012; 10:134.

7. Vagetti GC, Barbosa Filho VC, Moreira NB, Oliveira V, Mazzardo O, Campos Wd. Association between physical activity and quality of life in the elderly: a systematic review, 2000-2012. Rev Bras Psiquiatr. 2014; 36(1): 76-88.

8. Coons SJ, Rao S, Keininger DL, Hays RD. A comparative review of generic quality-of-life instruments. Pharmeconom. 2000; 17(1): 13-35. aktivnosti i HRQoL skorova kod starih osoba. Rezultati: Merenja su pokazala statistički značajnu razliku između visoko- i nisko aktivnih grupa ( $\mathrm{p}<0.05)$. Visoko aktivna grupa je pokazala viši HRQoL skor nego niskoaktivna grupa u svih 5 dimenzija. Niskoaktivna grupa je pokazala visoku zastupljenost hroničnih bolesti. Zaključak: Viši nivo fizičke aktivnosti je imao bolji efekat na sve dimenzije HRQoL kod starih osoba. Napor i svest o fizičkoj aktivnosti treba da budu posvećeni ohrabrenju da se usvoje novi aktivni stilovi života među različitim populacijama, naročito kod starih ljudi.

Ključne reči: stari, fizička aktivnost, HRQoL, EuroQoL.

9. Pattanaphesaj J, Thavorncharoensap M. Measurement properties of the EQ-5D-5L compared to EQ-5D-3L in the Thai diabetes patients. Health Qual Life Outcomes. 2015; 13:14.

10. Halaweh H, Willen C, Grimby-Ekman A, Svantesson U. Physical activity and health-related quality of life among community dwelling elderly. J Clin Med Res 2015; 7(11): 845-52.

11. Ortlieb S, Gorzelniak L, Nowak D, Strobl R, Grill E, Thorand B, et al. Associations between Multiple Accelerometry-Assessed Physical Activity Parameters and Selected Health Outcomes in Elderly People-Results from the KORA-Age Study. PLoS One. 2014; 9(11): e111206.

12. Svantesson U, Jones J, Wolbert K, Alricsson M. Impact of physical activity on the self-perceived quality of life in non-frail older adults. J Clin Med Res. 2015; 7(8): 585- 93.

13. Balboa-Castillo T, Leon-Munoz LM, Graciani A, Rodriguez- Artalejo F, Guallar-Castillon P. Longitudinal association of physical activity and sedentary behavior during leisure time with health-related quality of life in community- dwelling older adults. Health Qual Life Outcomes. 2011; 9(1): 47.

14. Van Oostrom SH, Smit HA, Wendel-Vos GC, Visser M, Verschuren WM, Picavet HS. Adopting an active lifestyle during adulthood and health-related quality of life: the Doetinchem Cohort Study. Am J Public Health. 2012; 102(11): e62-8.

15. Choi M, Prieto-Merino D, Dale C, Nuesch E, Amuzu A, Bowling A, et al. Effect of changes in moderate or vigorous physical activity on changes in health related quality of life of 
elderly British women over seven years. Qual Life Res. 2013; 22(8): 2011-20.

16. Machon M, Larranga I, Dorronsoro M, Vrotsou K, Vergara I. Health-related quality of life and associated factors in functionally independent older people. BMC Geriatrics. 2017; 17(1):19.

17. Haywood KL, Garratt AM, Fitzpatrick R. Quality of life in older people: a structured review of self-assessed health instruments. Expert Rev Pharmacoecon Outcomes Res. 2006; 6(2): 181-94.

18. Rabin R, de Charro F. EQ-5D: a measure of health status from the EuroQol Group. Ann Med. 2001; 33(5): 337-43.

19. Aburuz S, Bulatova N, Twalbeh M, Gazawi M. The validity and reliability of the Arabic version of the EQ-5D: a study from Jordan. Ann Saudi Med. 2009; 29(4): 304-8.

20. Azpiazu GM, Cruz JA, VillagrasaFerrer JR, AbanadesHerranz JC, Garcia MN, Valero de Bernabe FA. Factores asociados a mal estado de salud percibido o a mala calidad de vida en personas mayores de 65 aZos. Rev Esp Salud Publica. 2002; 76(6): 683-99.

21. Sun W, Aodeng S, Tanimoto Y, Watanabe M, Han J, Wang B, et al. Quality of life (QOL) of the community-dwelling elderly and associated factors: a population-based study in urban areas of China. Arch Gerontol Geriatr. 2015; 60(2): 311-6.
22. Frandin K, Grimby G, Mellstrom D, Svanborg A. Walking habits and health-related factors in a 70-year-old population. Gerontology. 1991; 37(5): 281-8.

23. Atalay OT, Cavlak U. The impact of unsupervised regular walking on health: A sample of Turkish middle-aged and older adults. European Review of Aging and Physical Activity. 2012; 9(1): 71-9.

24. Holland R, Smith RD, Harvey I, Swift L, Lenaghan E. Assessing quality of life in the elderly: a direct comparison of the EQ-5D and AQoL. Health Econ. 2004; 13(8): 793- 805.

25. Beitz R, Doren M. Physical activity and postmenopausal health. J Br Menopause Soc. 2004; 10(2): 70-4.

26. Global Recommendations on Physical Activity for Health. Geneva, 2010.

27. Tak E, Kuiper R, Chorus A, Hopman-Rock M. Prevention of onset and progression of basic ADL disability by physical activity in community dwelling older adults: a meta-analysis. Ageing Res Rev. 2013; 12(1): 329-38.

28. Acree LS, Longfors J, Fjeldstad AS, Fjeldstad C, Schank B, Nickel KJ, et al. Physical activity is related to quality of life in older adults. Health Qual Life Outcomes. 2006; 4:37.

29. Strawbridge WJ, Deleger S, Roberts RE, Kaplan GA. Physical activity reduces the risk of subsequent depression for older adults. Am J Epidemiol. 2002; 156(4): 328-34.

\section{Correspondence to / Autor za korespondenciju}

Walid Kamal Mohammed Abdelbasset,

Assistant Professor,

Department of Physical Therapy and Health Rehabilitation,

College of Applied Medical Sciences,

Prince Sattam bin Abdul-Aziz University,

Alkharj, Saudi Arabia.

E-mail: walidkamal.wr@gmail.com

Mobile: 00966561014872 